\title{
Drospirinone: new generation of progestogen
}

\author{
Ali Baziad
}

\begin{abstract}
Abstrak
Drospirinone merupakan jenis progestogen generasi baru yang memiliki khasiat antimineralokortikoid. Progestogen jenis ini telah digunakan sebagai komponen kontrasepsi kombinasi. Kontrasepsi kombinasi generasi lama mengandung komponen progestogen turunan testosteron. Progestogen jenis ini tidak memiliki khasiat antimineralokortikoid, sehingga menyebabkan retensi cairan. akibatnya, wanita yang menggunakan pil kombinasi jenis ini sering mengeluh sakit kepala, nyeri payudara, nyeri betis, peningkatan berat badan dan tekanan darah. Karena memiliki sifat androgenik, maka pil kontrasepsi kombinasi yang mengandung progestogen turunan testosteron dapat menimbulkan jerawat dan muka berminyak. Kontrasepsi kombinasi yang mengandung drospirinone tidak menyebabkan sakit kepala, nyeri payudara, nyeri betis, peningkatan berat badan dan tekanan darah. Drospirinone memiliki sifat antiandrogenik yang sangat kuat, sehingga tidak menimbulkan jerawat dan muka berminyak. Sebagai tambahan, kombinasi etinil estradiol dan drospirinone dapat dipakai mengobati sindroma pra-haid dan nyeri haid, serta drospirinone tidak mempengaruhi metabolisme lipid dan karbohidrat. (Med J Indones 2005; 14: 190-3)
\end{abstract}

\begin{abstract}
Drospirinone is a new generation of progestogen that possesses antimineralocorticoid effect. Progestogen of this type has been used as a component in combined contraceptives. The combined contraceptives of old generation contained progestogen component of testosterone derivative. Progestogen of this type does not have antimineralcorticoid effect, such that it could cause fluid retention. As a result, women who used combined pills of this type often complained of headache, breast pain, calf pain, increased body weight and blood pressure. Owing to its androgenic effect, combined contraception pills that contained testosterone-derived progestogen may cause acne and oily face. Combined contraception that contains drospirinone does not cause headache, breast pain, calf pain, increased body weight and blood pressure. Drospirinone has such a strong anti-androgenic nature that it does not result in acne and oily face. In addition, combination of ethinylestradiol and drospirinone can be used for treating pre-menstrual syndrome and menstrual pain. Drospirinone does not affect lipid and carbohydrate metabolism. (Med J Indones 2005; 14: 190-3)
\end{abstract}

Keywords: Drospirinone, oral contraceptive

Various types of progestogen have been produced. Up to the present, the most widely known type of progestogen has been testosterone-derived progestogen or progesterone-derived progestogen. Testosteronederived progestogen, such as acetate noretisterone, has for the most part been used as components of contraceptive pills, along with synthetic estrogen of ethynilestradiol, while progesterone-derived progestogen was widely used for treatment of gynecologic abnormalities, such as dysfunctional uterine bleeding, endometrial hyperplasia, and endometriosis.

Department of Obstetrics and Gynecology, Faculty of Medicine, University of Indonesia / Dr. Cipto Mangunkusumo Hospital, Jakarta, Indonesia
Testosterone-derived progestogen was used as a component of combined contraceptive pills because this progestogen was very strong in suppressing FSH and LH secretion, such that it was highly effective in suppressing ovulation, and thereby leading to lower pregnancy rates.

Compliance in the use of contraceptive pills is extremely important. Discomfort or side effects arising from the use of contraceptive pills may result in low compliance rates of patients. Up to now, contraceptive pills available in Indonesia generally have contained testosterone-derived progestogen, resulting in the negative effects such as acne, increased body weight and blood pressure, and headache. Some of the aforementioned impacts were generally due to fluid retention, because all types of testosterone-derived progestogen do not have the effect of preventing fluid 
retention. ${ }^{1}$ This fluid retention may cause pain in the calf and breast.

In order to overcome these negative impacts, combined contraceptive pills containing a new generation of progestogen, or drospirinone, have been produced, which is known as Yasmin for its commercial name. Drospirinone has a very strong antimineralcorticoid effect that it does not cause fluid retention. In addition, drospirinone has a powerful antiandrogen effect, ${ }^{2}$ which may prevent the outbreak of acne and oily face skin.

\section{Profile of Drospirinone}

As explained before, almost all combined contraceptive pills contain strong synthetic estrogen of testosterone-derived ethynilestradiol and progestogen. Ethynilestradiol triggers the formation of angiotensinogen in the liver. Renin changes angiotensinogen into angiotensin I, and subsequently angiotensin I is changed by enzyme into angiotensin II and dipeptide. Angiotensin II triggers the secretion of aldosterone in the suprarenal cortex, leading to fluid retention and finally resulting in increased plasma volume, increased blood pressure and body weight, calf and breast pain. $^{2,3}$ (Figure 1).

Testosterone-derived progestogen does not have antimineralcorticoid effect such that it cannot prevent the negative impacts of ethynilestradiol. Therefore, another type of progestogen was sought to eliminate the negative impacts of ethynilestrodiol on fluid retention. This type of progestogen is drospirinone. Drospirinone is a progesterone-derived progestogen that possesses a very strong antimineralcorticoid effect. A new type of combined contraceptive pill of ethynilestradiol and drospirinone has bee produced, i.e. Yasmin. Because of relatively low side effects, it is expected that this new type of contraceptive pill will increase patient's compliance.

Obesity and outbreak of acne have created a forbidding problem for contraceptive acceptors. Drospirinone with its strong antimineralcorticoid and antiandrogenic effects has proved to be effective in reducing body weight and outbreak of acne. By preventing the occurrence of fluid retention, breast and calf pain, headache, and increased blood pressure may also be averted.

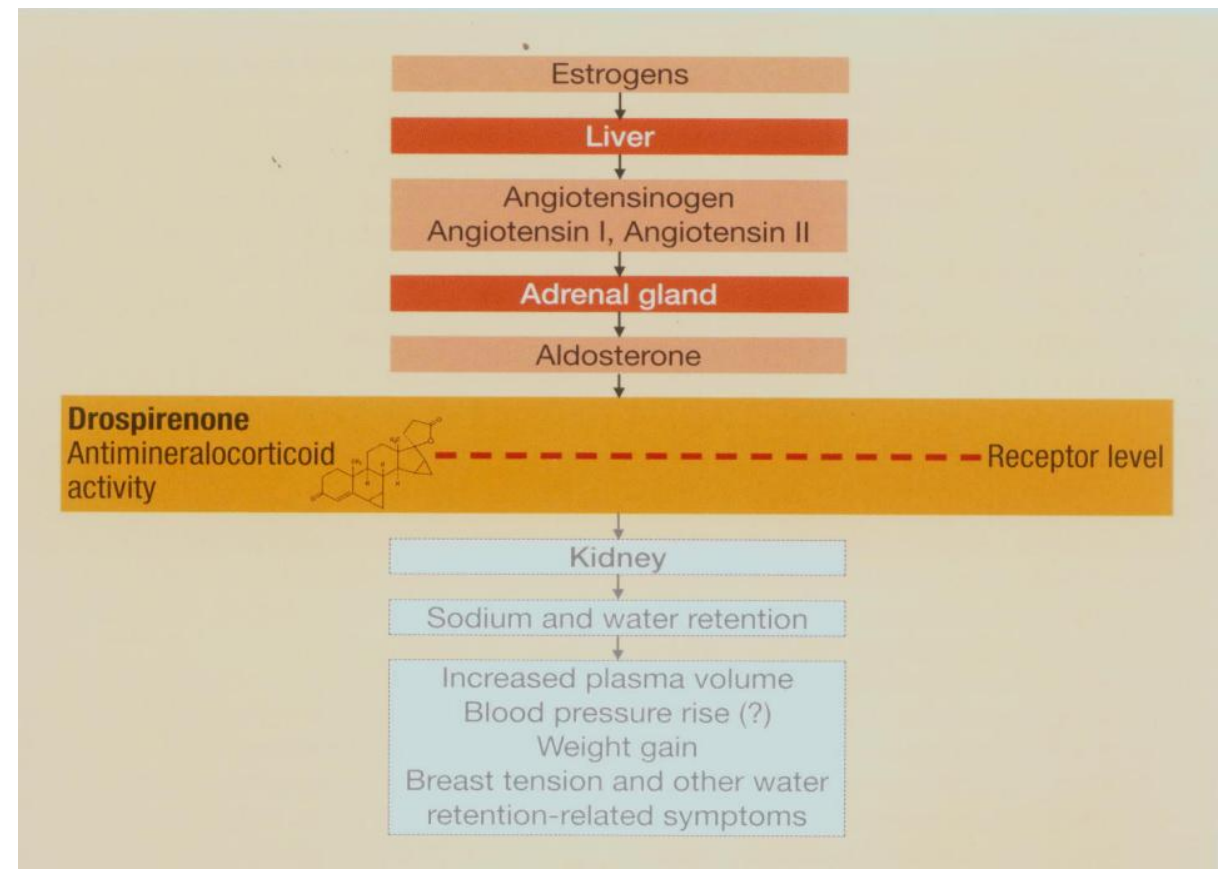

Figure 1. A schematic of the pharmacological and possible clinical effects of mineralocorticoid and antimineralocorticoid activity. 


\section{Lipid and carbohydrate metabolism}

Since drospirinone constitutes a progesterone-derived progestogen, it affects lipid metabolism only very slightly. The administration of combined contraceptives of ethynilestradiol and drospirinone resulted in a significant increase of HDL. ${ }^{4}$ As known, HDL is a lipoprotein that possesses a cardioprotective effect. Only slight changes occur in the carbohydrate metabolism during the use of this contraceptive pill.

\section{Pre-menstrual syndrome}

Prior to menstruation, most women complain of headache, swollen leg, breast pain, being overly sensitive, depression, and distended abdomen. The exact causes of these complaints have not been known. Headache, swollen leg, breast pain are closely associated with fluid retention. It has been shown that the administration of progesterone may eliminate these complaints.
Because drospirinone has the effect of preventing fluid retention, this type of progestogen or contraceptive pill that contains drospirinone could be used to treat the complaints of pre-menstrual syndrome. ${ }^{5}$ (Figure 2).

\section{Dysmenorrhea}

Menstrual pain or dysmenorrhea is frequently encountered in young women. During reproductive age, menstrual pain is generally caused by endometriosis. If it is aimed only to eliminate the complaint of menstrual pain, either combined contraceptive pills or contraceptive pills that contain only progestogen are very effective in eliminating menstrual pain $(1,6)$. Because drospirinone possesses a very strong antiandrogenic effect, contraceptive pills containing drospirinone are very appropriate to be administered to young women with menstrual pain, particularly because during this period young women generally break out in an acne and oily skin.

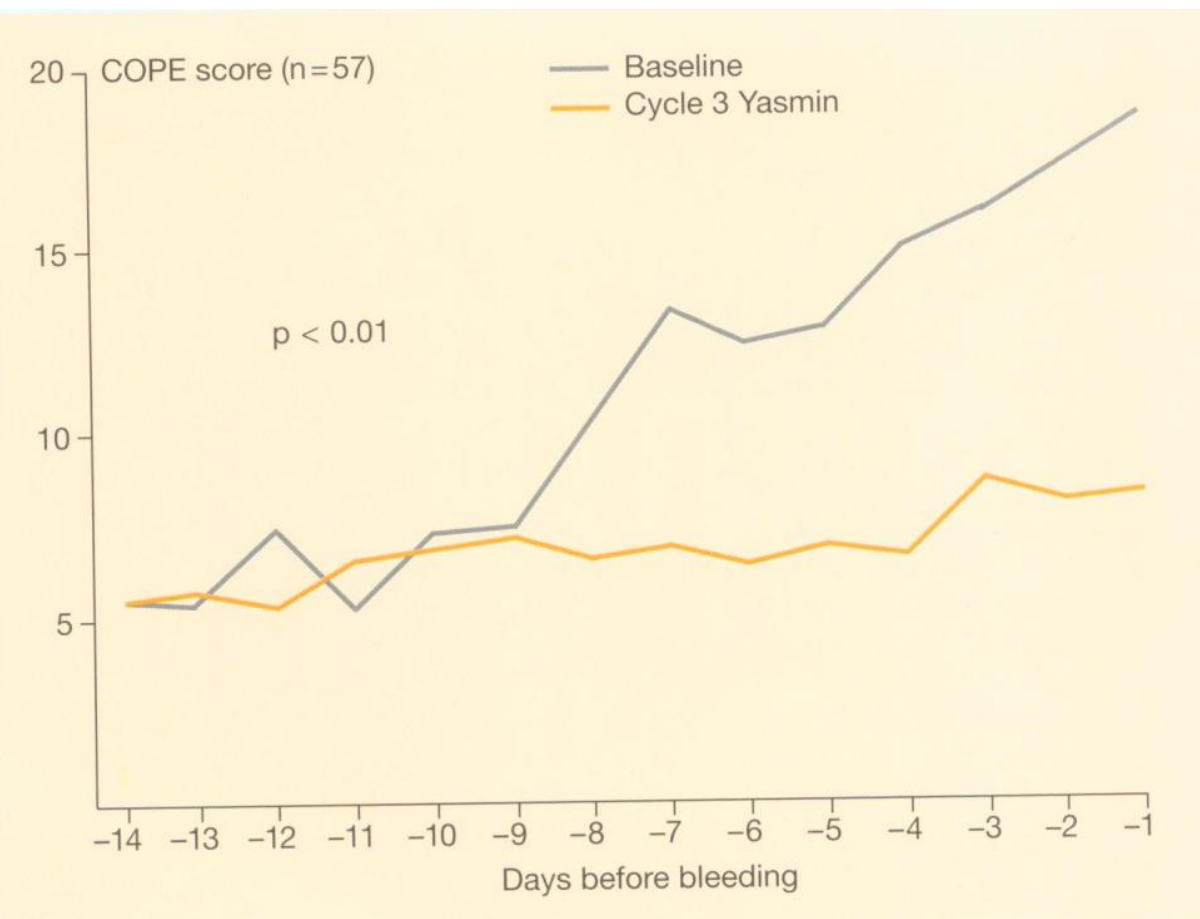

Figure 2. Yasmin prevents the increase in the COPE (calendar of premenstrual experiences)score which is a future in untreated women during the premenstrual period. 


\section{Acne and skin}

The use of combined contraceptive pills containing testosterone-derived progestogen may result in the outbreak of acne and oily skin. Acne and oily skin are caused by high-level androgen in the blood. Several types of progesterone-derived progestogen, such as drospirinone, chlormadinon acetate and cyproteron acetate, produce antiandrogenic effects, by occupying androgen receptor at the target organ. After the administration of combined contraceptive pills containing drospirinone (Yasmin), a decrease in sebum production and acne lesion was observed. ${ }^{2}$ (Figure 3 ).

\section{CONCLUSIONS}

Drospirinone is a progesterone-derived progestogen that has been used as a contraceptive component, along with ethynilestradiol. Because drospirinone possesses antimineralcortioid quality, it does not cause fluid retention, such as increased body weight and blood pressure, also headache, calf and breast pain can be prevented. Owing to its antiandrogenic effect, drospirinone is effective in preventing the outbreak of acne and oily skin. In addition, combined contraceptive pills containing ethynilestradiol and drospirinone can be used for treating premenstrual syndrome and menstrual pain. Drospirinone does not affect lipid and carbohydrate metabolism.

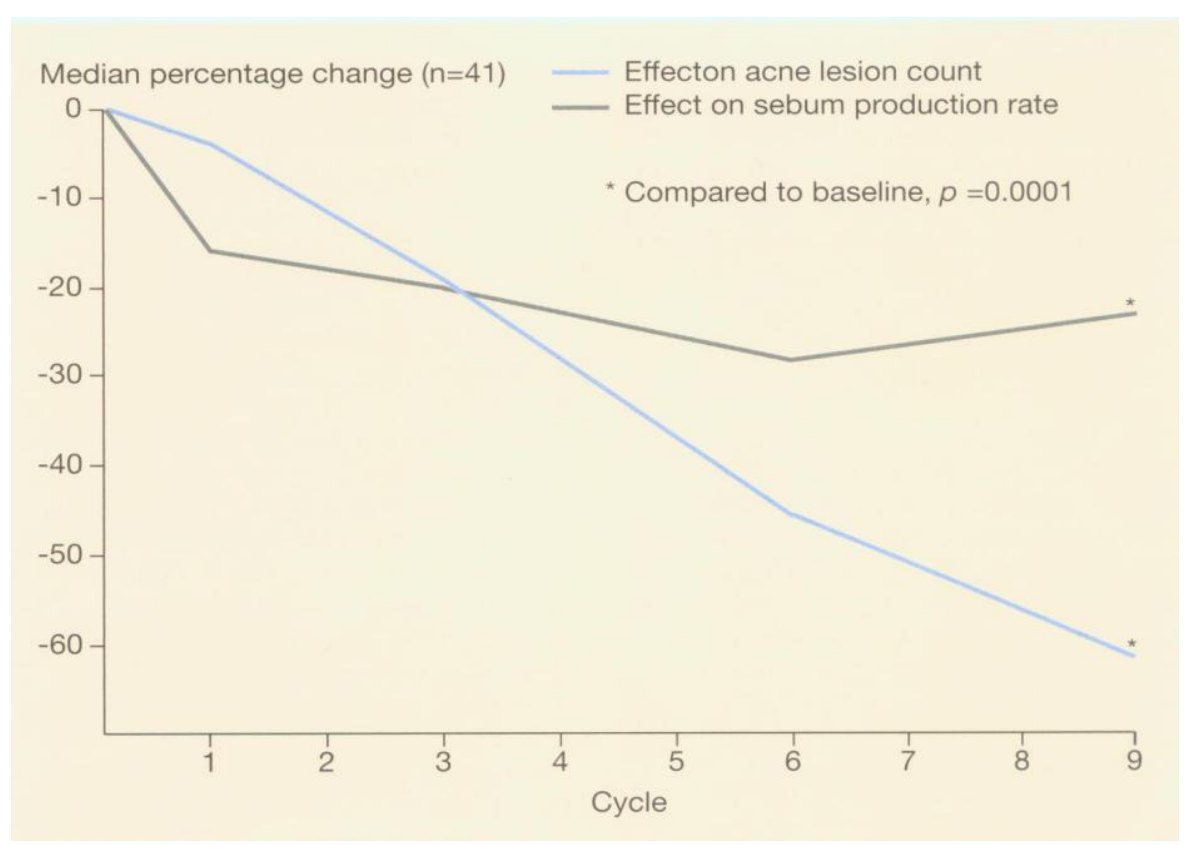

Figure 3. Antiandrogenic effects of Yasmin on acne lesions and sebum production

\section{REFERENCES}

1. Sillem M, Schneidereit R, Heithecker R, Mueck AO. Use of an oral contraceptive containing drospirinone in an extended regimen. Euro J Contr Reproduc Health Care 2003;8:162-68.

2. Yasmin. Product Monograph. Schering.

3. Oelkers W, Berger V, Bolik A et al. Dihydrospirinone- a new progestogen with antimineralocorticoid activity: Effects on ovulation, electrolyte exretion and the renninaldosterone system in normal women. J Clin Endocrinol Metab 1991;73: 837-42.
4. Oekers W, Foidart J-M , Dombrovicz N et al. Effects of a new oral contraceptive containing an antimineralocorticoid progestogen drospirinone on the rennin-aldosterone system, body weight, blood pressure, glucose tolerance and lipid metabolism. J Clin Endocrinol Metab 1995 ;80: 1816-21.

5. Brown C, Ling F, Wan JA. A new monophacic oral contraceptive containing drospirinone effect on premenstrual symptoms. J Reprod Med 2002;47:14-22.

6. Riva HL, Kawasaki DM, Messinger AJ. Further experience with norethynodrel in treatment of endometriosis. Obstet Gynec 1969;19:111-7. 